Journal of Social Sciences (COES\&RJ-JSS)

ISSN (E): 2305-9249 ISSN (P): 2305-9494

Publisher: Centre of Excellence for Scientific \& Research Journalism, COES\&RJ LLC

Online Publication Date: $1^{\text {st }}$ April 2017

Online Issue: Volume 6, Number 2, April 2017

http://centreofexcellence.net/J/JSS/JSS\%20Mainpage.htm

\title{
Managing Egyptian Tourism \\ through Tourism Governance
}

Dr. Yasmine Ramzy

Arab Academy for Science, Technology and Maritime Transport

Gamal Abdel Nasser, Miami, Alexandria, Egypt.

\begin{abstract}
:
Egyptian tourism has been hit by years of political upheaval and militant violence. Egypt's tourism authorities expect the number of tourists to drop by 13 percent in 2015/2016, compared to the year before, reaching 9 million tourists and revenues are expected to fall by 15 percent compared to last year, dropping to $\$ 6.2$ billion. Egypt depends on the tourism sector as a main contributor to the country's GDP and has been engaged in attempts to revive the ailing sector that has been reeling from years of political turmoil. To deal with the tourism crisis, the Egyptian authorities agreed to allocate $\$ 5$ million to support the sector. They agreed to launch a massive campaign to promote internal tourism. However, this is not enough, better management techniques should be adapted in Egyptian tourism industry. Tourism governance could be a useful tool for managing Egyptian tourism. This could be beneficial because tourism is a sector of activity that involves multiple interrelationships among various types of stakeholders intervening in the production of goods and services consumed by tourists. Indeed, this study overall objective is to analyze governance and positioning of local actors face to manage tourism, in order to establish parameters for more effective tourism management, giving answer for questions like: what are the various issues of governance planning in relation to the development of Egypt as sustainable tourism destination?, and what is the level of commitment of stakeholders to get effectively and efficiently management?

Keywords:

Egyptian Tourism, Tourism Governance, Stakeholders Partnership

Citation:

Ramzy, Dr. Yasmine (2017); Managing Egyptian tourism through tourism governance; Journal of Social Sciences (COES\&RJ-JSS), Vol.6, No.2, pp: 196-210.
\end{abstract}




\section{Introduction}

Egyptian tourism has been hit by years of political upheaval and militant violence. Before 2011, Egyptian tourism was a rising star in the struggling economy. During this period, the share of tourism revenues in Egypt's account receipts reached the $20 \%$. Tourism had become the largest single source of foreign exchange earnings for the Egyptian economy. Using the foreign currencies of millions of tourists, the country was able to overcome its recurrent balance of payments problems. Following the 2011 January uprising, the influx of tourists declined by 4.8 percent to hit 9.9 percent in 2014, according to the Central Agency for Public Mobilization and Statistics (CAPMAS).Additionally, Egypt has witnessed a rise in attacks on soldiers and police since 2013. Although, Egyptian officials' authorities have made great progress in the battle against militants, Egypt's tourism authorities expect the number of tourists to drop by $13 \%$ in $2015 / 2016$, compared to the year before, reaching 9 million tourists and revenues are expected to fall by $15 \%$ compared to last year, dropping to $\$ 6.2$ billion. Finally, Egypt depends on the tourism sector as a main contributor to the country's GDP and has been engaged in attempts to revive the ailing sector that has been reeling from years of political turmoil.

To deal with the tourism crisis, the Egyptian authorities agreed to allocate $\$ 5$ million to support the sector. They agreed to launch a massive campaign to promote internal tourism. However, this is not enough, better management techniques should be adapted in Egyptian tourism industry. Tourism governance could be a useful tool for managing Egyptian tourism. Tourism governance means the process of managing tourist destinations through synergistic and coordinated efforts by governments, at different levels and in different capacities; civil society living in the inbound tourism communities; and the business sector connected with the operation of the tourism system" (UNWTO, 2013). This could be beneficial because tourism is a sector of activity that involves multiple interrelationships among various types of stakeholders intervening in the production of goods and services consumed by tourists. Accordingly, the government's functions, under current conditions, are particularly relevant in coordinating efforts to help ensure that the dynamic of permanent growth that tourism has achieved to date is economically, socially and environmentally sustainable so as to increase its contribution to development.

Egypt includes a large network of public and private partners who have a diversity of interests and perspectives, but also include a large numbers of economic activities which make tourism management a challenge. This difficulty increases because Egypt has several types of tourism and contains a diversified ecosystem with high biological value. It is possible to say that Egyptian stakeholders have different goals and knowledge of tourism, which affected tourism management. The analysis of the level of commitment concluded that the various local stakeholders have different levels of commitment but all are more or less committed. The actors who provide the highest level of interest are the communities, private sector, and ministry of tourism where tourism is a priority. Regarding governance there are four main problems that affected collaboration among different stakeholders and, as a priority, the management of tourism. In the first place, the government administrative hierarchy and the lack of communication between stakeholders generate a significant slowdown of management. In addition, there are real problems, such as between ministries, private sector and communities, problems of divergence of point of views regarding tourism management and development issues. There is a certain level of governance which is very complicated, with a lack of information and little coordinated efforts between stakeholders. Local communities must be active participants in tourism 
management process. To achieve this goal, there must be a compromise of locals, but also it is necessary that other public and private actors work closely to give security to local residents.

The study overall objective is to analyze governance and positioning of local actors face to manage tourism, in order to establish parameters for more effective tourism management, giving answer at questions like What are the various issues of governance planning in relation to the development of Egypt as sustainable tourism destination?, and what is the level of commitment of stakeholders to get effectively and efficiently management?

The research was based on a hypothetical-deductive methodology which, in its first stage envisaged the creation of a hypothesis, and then observing application of tourism governance through a literature review and visiting government officials to conduct interviews. According to research objectives, two hypotheses were considered. The first states that "The various objectives of various stakeholders and levels of knowledge and experience in Egyptian tourism industry affect the management of Egypt as a destination" the study of this hypothesis defined the objectives of each actor and its level of knowledge related to tourism. The second hypothesis states that "The effectiveness of institutional structures and the relationship between stakeholders would have a direct impact on governance, management and development of local tourism". This means that tourism management is affected directly by the relationships between actors that are present in Egypt. The analysis of these two hypotheses allowed understanding governance's issues and evaluation of the tourism management that could be applied, but also provided an opportunity to identify key work to promote Egypt globally as a safe tourism destination through several processes including public and private actors who have an influence on the industry.

\section{Literature Review}

Introducing Tourism Governance

Governance is an ancient word that dates back to the early civilizations. Several authors recognize that its use in modern language dates back the end of middle ages (Kjaer, 2005; Calame, 2009). In fact, governance refers to a stable environment conducive to investment and to a political system and public administration capable of responding to citizens' demands in democratic, participatory and transparent manner (Niferini, 2011). The term governance has been defined by several international organizations such as the World Bank, the United Nations Development Programme (UNDP), European Union (EU) and others. Indeed, the World Bank (2009) stated that "governance consists of the traditions and institutions through which authority is exercised in a country. This includes the process by which governments are elected, overseen and replaced; the government's capacity to effectively formulate and carry out good public policies and the extent to which citizens respect the State and the institutions that govern economic and social interactions."

Moreover, governance could be seen as a social phenomenon in which both public and private governing actors participate (interactive or sociopolitical government), their roles sometimes varying according to social level and from one sector to another; it is a combination of all types of activity and government structure, in which public and private sector actors seek solutions to three basic questions: solving social problems or creating social opportunities; giving attention to the social institutions in which government 
activities take place; and agreeing on principles so that government activities can take place. Governance is thus a useful instrument for conceptualizing the problems, opportunities and contexts and the boundaries between the State, the market and civil society (Kooiman, 2008). Indeed, responses to diverse, dynamic and complex societal issues (including planning and development) require approaches involving previously uninvolved partners, looking not only at the market as seems to have been an almost universal response in recent years, but also looking at 'civil society' actors, as serious governing partners (Kooiman,2000).

There are three broad modes of governance in literature; centralized, decentralized and shared governance. First, there is centralized governance or hierarchal governance. This mode is state centric and includes top- down structures, centralization, bureaucracy, command and control (Gray, 2005). The second mode is decentralized governance. It focuses on low levels of governments involved in management (De Oliviera, 2002). Additionally, De Oliviera (2002) discusses three forms of decentralization. These are deconcentration, delegation and devolution. Deconcentration implies the transfer of tasks in a government agency from central office to offices located closer to population. In contrast, delegation involves decentralizing tasks from the central government to other public organizations. Finally, devolution requires complete the complete transfer of decisions regarding certain public responsibilities from a central government to lower level government (De Oliviera, 2002). The third and last mode of governance is shared governance. This mode has emerged more recently. It means the sharing of responsibility and authority between government, private sector and local community and can be understood as a "multi- track approach" at a local and national scale, usually involving two or more groups (Pomeroy and Berks, 1997). This mode of governance could be adapted in tourism governance because it involves different stakeholders. Thus, it could be the best mode of governance implemented to manage Egyptian tourism.

Generally, many studies indicate that governance and its efficiency have an important influence on economic growth and social development (Gray, 2005; Nordin and Svennsson, 2007). Governance plays an essential role as one of the institutional factor affecting economic growth (Connelly, 2007). Indeed, government incompetence, corruption, inefficiency and lack of reactive capacity are vital for economic growth. Since tourism and governance are both vital for economic growth. UNWTO (2013)stated that tourism destination has the features of multi-actor complexity, resource dependence between actors involved and public-private interplay, so the governance perspective is well suited for understanding the dynamics of a certain destination.Therefore, tourism governance is essential for economic growth and economic development. Nordin and Svennsson (2007) explored the link between tourism governance structure and destination development and growth in order to discover whether and how tourism governance matter in terms of performance. Their results indicate that stakeholders' relationships built on trust; joint risk- taking, informal structures and strategic consensus do have a positive impact on the level of growth at a tourist destination.

Additionally, the dynamic of growth in tourism, as well as the need to increase its contribution to development, heighten the need for the various public, private and local community actors intervening in tourism production at any level (national, subnational, supranational) to reach understandings and complementarily that draw in a balanced way on their respective capacities and resources for the direction, organization and 
management, and, if considered appropriate, to achieve synergies; but first of all, to organize themselves and cooperate in defining and pursuing general objectives beneficial to society as a whole, diminishing the negative impact that tourism activity has tended to generate (UNWTO, 2013).In tourism industry, decision-making and development processes require multi-stakeholder involvement at all levels of planning and policymaking, bringing together governments, NGOs, residents, industry and professionals in a partnership that determines the amount and kind of tourism that a community wants (Hwansuk and Sirakaya, 2006). As a matter of fact, tourism is a sector of economic activity that is defined as groups of units of production in different industries (tourism industries) that provide the consumer goods and services to meet demand generated by visitors. However, and according to the definition of governance, networks are structures made up of organizations for the exchange of resources. They are characterized by a capacity for self-organization and government and by relatively stable patterns of social relationships among interdependent actors focusing on public policy problems and/or programs with the aim of achieving their objectives and maximizing their influence over results (UNWTO, 2013).

\section{Tourism Governance in Egypt}

Egypt is a transcontinental country with a unique geographical position in Northeast Africa, at the crossroads of Europe and Asia, on the Mediterranean and Red Sea, and its connection to Sub Saharan Africa through the Nile Valley. Egypt is at the center of the Arab world and controls the Suez Canal, the shortest sea link between the Indian Ocean and the Mediterranean Sea. The country is defined by desert and the Nile, the longest river on Earth. Egypt is a well- known tourism destination. This is due to its ancient civilization, which enriches it with historical sites and its unique geographical location. Egypt has witnessed significant political and economic changes since 2011. Through this transition, which includes periods of political unrest, the main income sources of the economy have been negatively impacted, particularly in the tourism sector, as well as revenues from the Suez Canal, oil and remittances from Egyptians working abroad, affected by the global economy.

However, before this period Egyptian tourism has experienced significant growth bringing considerable benefits to all actors involved in the tourism industry such as government suppliers, intermediaries and tourists themselves. However, conflicts between the different actors have become increasingly intense, which in turn has negatively affected the process of tourism development. The Egyptian government main objective is economic growth and diversifying economic activities. Indeed, national economic growth enlarges output that can satisfy domestic and international demand. Also, it provides more jobs and expanded incomes for residents. A growing national economy increases revenues available to governments to finance services for residents in the way of defense, education, security, social welfare support, infrastructure and other beneficial services. In short, a steadily growing national economy increases the choices available to residents and institutions that lead to improving the quality of life for all (Frechtling, 2013). Finally, tourism's impact on the economic and social development in Egypt can be enormous; opening it up for business, trade and capital investment, creating jobs and entrepreneurialism for the workforce, protecting heritage and cultural values and reduce poverty. 
Moreover, the direct contribution of tourism to Egyptian GDP in 2014 was EGP117.2bn (5.9\% of GDP) (see figure 1). This primarily reflects the economic activity generated by industries such as hotels, travel agents, airlines and other passenger transportation services (excluding commuter services). But it also includes, for example, the activities of the restaurant and leisure industries directly supported. The direct contribution of Travel \& Tourism to GDP is expected to grow by $4.5 \%$ to EGP187.7bn (5.6\% of GDP) by 2025 . Additionally, tourism generated 1,322,500 jobs directly in 2014 (5.2\% of total employment). This includes employment by hotels, travel agents, airlines and other passenger transportation services (see figure 2). It also includes, for example, the activities of the restaurant and leisure industries directly supported by tourists. By 2025, tourism will account for $1,708,000$ jobs directly, an increase of $2.0 \%$ over the next ten years (WTTC, 2015).
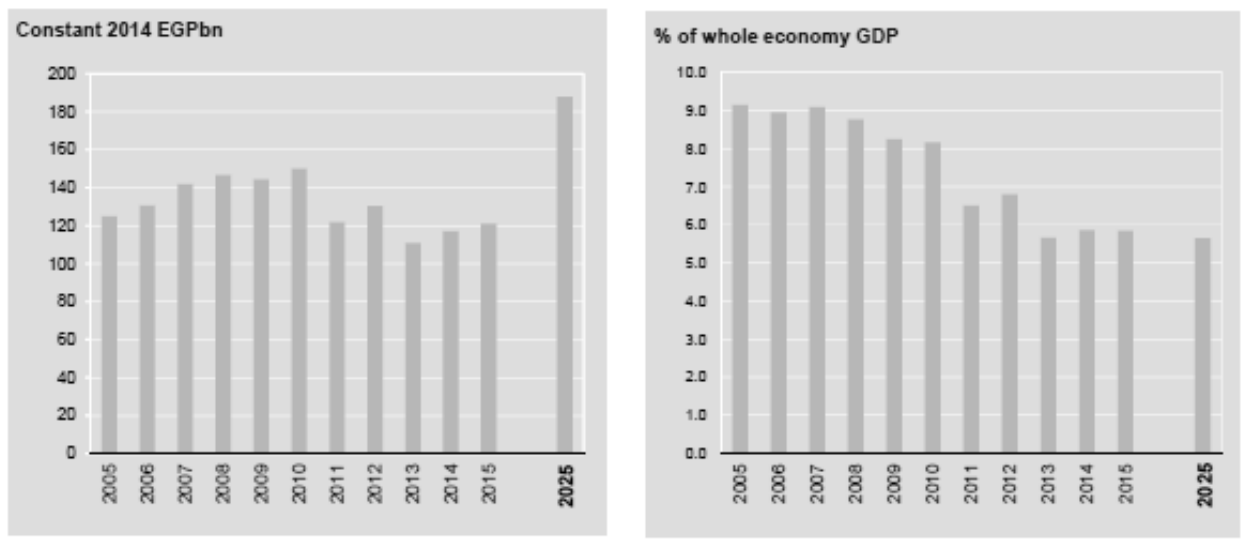

Figure 1: Direct Contribution of Tourism to Egyptian GDP (Source: WTTC 2015)
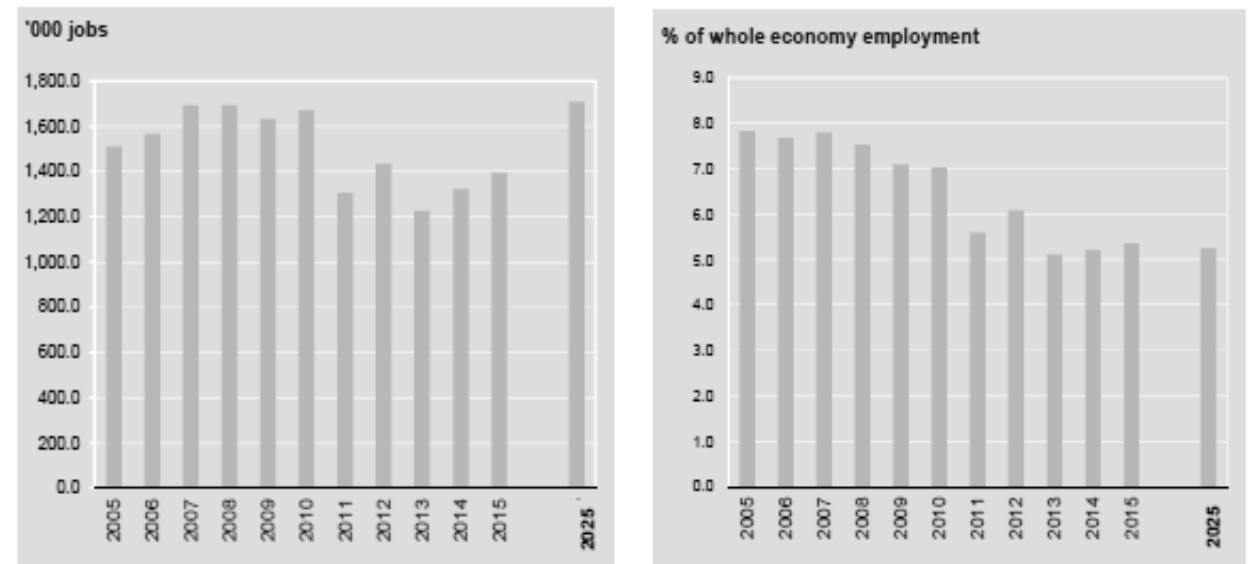

Figure 2: Direct Contribution of Tourism to Egyptian Employment (Source: WTTC 2015) 
Additionally, international tourist arrivals to Egypt reached 11.5 million in 2012, generating a total of USD 9.9 billion in revenues, or around $14.4 \%$ of total current receipts, and $45 \%$ of all services export receipts. Travel receipts also constituted the fourth largest item in terms of generating foreign currency earnings. The total number of international tourist nights rose to 137.8 million in 2012, 20.6\% more than in 2011 (Box 1). About $73 \%$ of Egypt's inbound tourists came from Europe - and around 50\% from five countries: the Russian Federation, the United Kingdom, Germany, Italy and France - with the vast majority arriving by air $(82.8 \%)$. Recreational tourism continues to dominate demand, accounting for some $94.8 \%$ of all international visitor arrivals.

In fact, the benefits of tourism accruing to Egypt depend to a large extent on the critical role played by the government, which in the mainly the ministry of tourism that has the mandate to govern and regulate the tourism sector (Jeffries, 2001). As with any other economic activity, the character, role, function and influence of the government determine the location and nature of tourism development activities, who gets to participate in these activities and how the benefits are (re)distributed (Hall, 1998). As a result of this, for tourism to be beneficial, the government has to be able to intervene and encourage its development. This is explained by Jeffries (2001) as a "complex structure of governmental and official recognized institutions ... existing at different levels within a pyramid, the national executive at the apex and the local level at the base". The degree of complexity and levels of institutions differ from country to country, as the response to the challenge posed by tourism is expressed in different organizational structures.

The Egyptian Ministry of Tourism is responsible for tourism policy (Figure1) and for establishing a coherent legal and regulatory framework for tourism development. Both the Egyptian Tourism Authority (ETA) and the Tourism Development Authority (TDA) fall under the jurisdiction of the ministry.

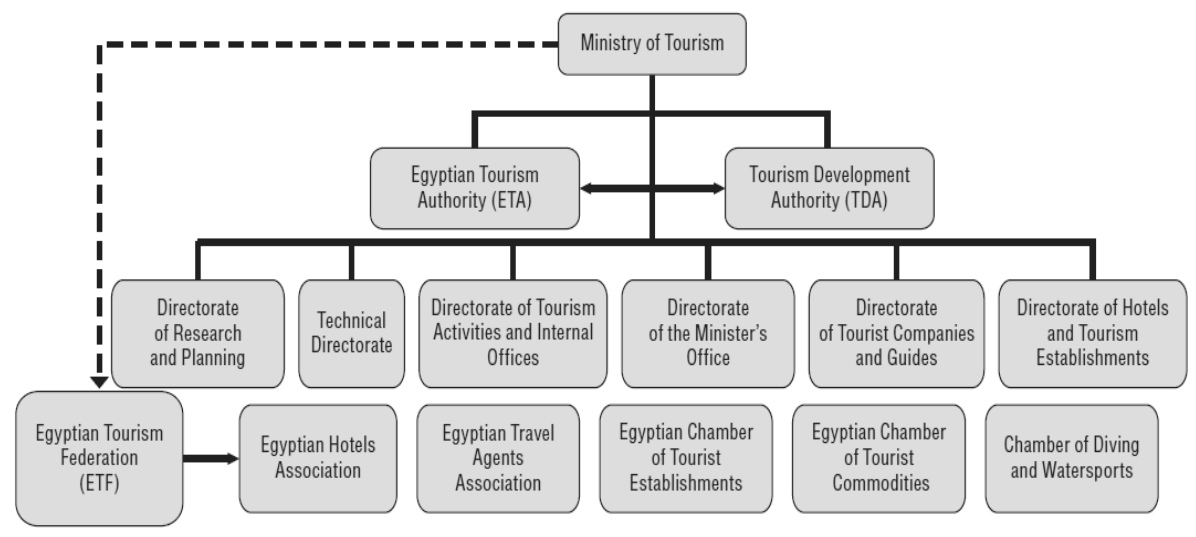

Source: OECD, adapted from the Ministry of Tourism, 2014.

Figure1: Organizational Chart of Organizational Bodies in Egypt

The TDA works primarily on setting and implementing regulations for tourism projects and investments by assisting with the provision of land and facilitating access to loans for developing infrastructure projects. Seeking to reduce administrative regulations, the TDA is adopting a one-stop shop system in the context of institutional and legislative reform in the sector, and is developing a legal framework for guarantees and investment incentives. 
The TDA is leading the "Green Sharm Initiative" project, the "Development of religious tourism in the Farma area of North Sinai" project, and the Strategic Plan for Tourism Development in the New Valley governorate. The ETA is responsible for promoting inbound and domestic tourism. It manages the development and diversification of the tourism product, both regionally and internationally, and is working on creating a new "Egypt tourism brand".

The Egyptian Tourism Federation (ETF) represents the Egyptian private sector enterprises. It is composed of five tourism industry business associations (see figure 4): the Egyptian Hotels Association, the Travel Agents' Association, the Chamber of Tourist Establishments, the Egyptian Chamber of Tourist Commodities and the Egyptian Chamber of Diving and Water sports. It works closely with the Ministry of Tourism in areas related to tourism planning, and for managing the Tourism Workforce Skills Development Project. By law, ETF's views are considered before any new legislative measures. The successful collaboration between the Ministry of Tourism and the ETF establishes a good model of public-private partnership. In fact, Tourism has attracted private sector investment of EGP30.6bn in 2014. This is expected to rise by $5.1 \%$ over the next ten years to EGP50.8bn in 2025 (see figure 4). Tourism's share of total national investment will rise from $11.0 \%$ in 2015 to $11.2 \%$ in 2025 .

\begin{tabular}{|c|c|c|c|c|c|}
\hline & 2008 & 2009 & 2010 & 2011 & 2012 \\
\hline Total tourism enterprises & 18923 & 17524 & 20729 & 22083 & 19668 \\
\hline Tourism industries & .. & .. & .. & & \\
\hline Accommodation services for visitors ${ }^{1}$ & 1490 & 1458 & 1473 & 1473 & 1267 \\
\hline Hotels and similar establishments &. & .. &. & 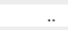 & \\
\hline Food and beverage serving industry ${ }^{2}$ & 1182 & 1201 & 1034 & 1185 & 1114 \\
\hline Passenger transport & .. & .. & .. & & \\
\hline Air passenger transport & .. & .. & .. & .. & .. \\
\hline Railways passenger transport &.. & .. & .. &.. & . \\
\hline Road passenger transport &.. & .. & .. &.. & . \\
\hline Water passenger transport & .. & .. & .. & .. & \\
\hline Passenger transport supporting services & .. & .. & .. & .. & . \\
\hline Transport equipment rental & & 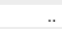 & 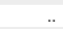 & & \\
\hline Travel agencies and other reservation services industry & 15896 & 14507 & 17861 & 19052 & 16914 \\
\hline Cultural industry & .. & .. & .. & .. & . \\
\hline Sports and recreation industry ${ }^{3}$ & 355 & 358 & 361 & 373 & 373 \\
\hline Retail trade of country-specific tourism characteristic goods & .. & .. & .. & .. & .. \\
\hline Other country-specific tourism industries & .. & .. & .. & .. & . \\
\hline Other industries &.. & .. & .. &.. & . \\
\hline $\begin{array}{l}\text { 1. Includes hotels, tourist villages and floating hotels. } \\
\text { 2. Restaurants, cafeterias and night clubs. } \\
\text { 3. Diving centres. } \\
\text { Source: }\end{array}$ & & & & & \\
\hline
\end{tabular}

Figure3: Egyptian Private Sector Enterprises (Source: OECD, 2014)
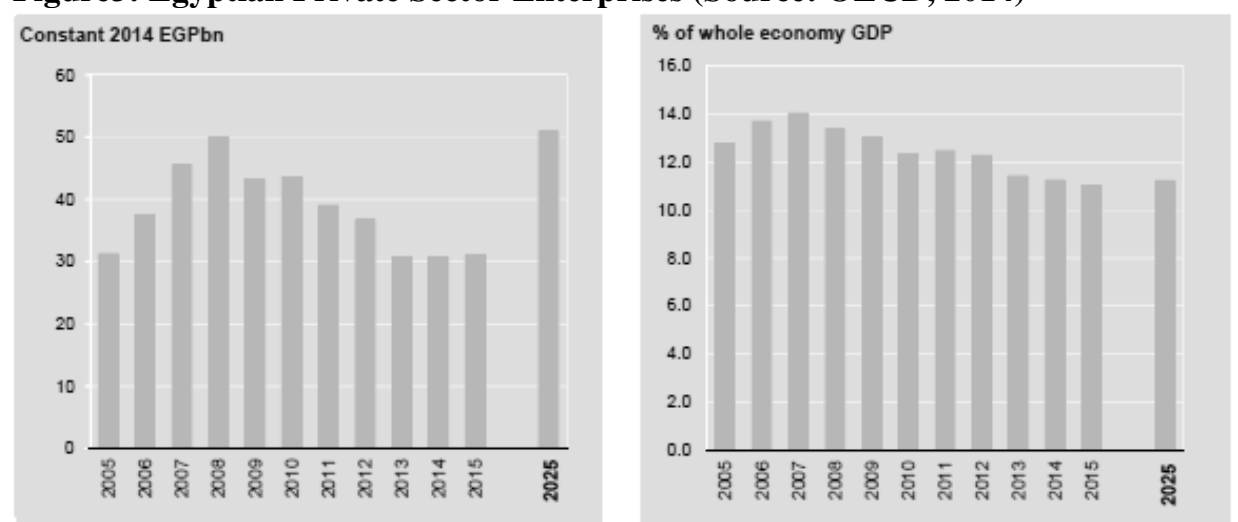

Figure 4: Private sector investment in Egyptian tourism industry (Source: WTTC 2015) 
Moreover, the current nature of the Egyptian tourism industry, high fragmentation and interdependencies across geographical spaces, led to the situation where its governance and regulation are not left solely in the hands of the government, but also in the hands of the many different actors and interest groups. Consequently, there is now a renewed focus on the need for coordination and collaboration between the different stakeholders (public, private and local community) in tourism governance and regulation in a tourist destination. Therefore, tourism governance could be a good solution for tourism management and thus development. As stated by Kooiman (2008) governance is about steering actions; it implies less government control and predictability, no self-evident leadership and no given hierarchy; it involves multiple stakeholders.

Moreover, governance is a practice of government that is measurable, that is aimed to effectively direct the tourism sectors at the different levels of government through forms of coordination, collaboration and/or cooperation that are efficient, transparent and subject to accountability, that help to achieve goals of collective interest shared by networks of actors involved in the sector, with the aim of developing solutions and opportunities through agreements based on the recognition of interdependencies and shared responsibilities. Public-private partnerships, understood broadly as tools for producing relevant changes in public administration are especially important in this context, particularly in a sector of activity like tourism where interaction among an extensive and complex range of actors and agents, public and private, is basic and indispensable for the production of tourism consumer goods and services. The different forms of collaboration should not be limited however, to the public-private sphere. They should also extend to relations between public administrations themselves and between them and local communities, given that most modern states are structured on a territorial basis based on complex, multilevel models requiring fluid intergovernmental relations or effective and crosscutting systems of collaboration and transfers of knowledge among the different spheres of public administration (UNWTO, 2013).

It should be noticed that tourism governance is still a new concept in Egypt in its modern sense. Indeed, the concept widely known in Egypt nowadays is "corporate governance". Corporate governance is defined as the rules, laws and standards that define the relationship between the company's management and its shareholders and stakeholders or related parties, namely the bondholders, workers, suppliers, creditors and consumers. Corporate governance is important because, if applied properly, it helps to realize high and sustainable growth rates in financial markets. It increases confidence in the national economy, deepens capital market and increases its ability to mobilize savings and raise investment rates. Moreover, it protects the rights of the minority shareholders or small investors. Corporate governance also encourages the growth of the private sector by supporting its competitive capabilities, helping to secure financing for projects, generating profits and creating job opportunities (WTTC, 2015). There is a huge difference between corporate governance and tourism governance. However, they both aim to ensure transparency and protection of stakeholders' rights.

\section{Research Methodology}

The research was based on a hypothetical-deductive methodology which, in its first stage envisaged the creation of a hypothesis, and then observing the application of tourism governance through a literature review and visits to concerned parties to conduct semistructure interviews. According to research objectives, two hypotheses were considered. 
H1: "The various objectives of various stakeholders and levels of knowledge and experience in Egyptian tourism industry affect the management of Egypt as a destination" The study of this hypothesis defined the objectives of each actor and its level of knowledge related to tourism.

H2:"The effectiveness of institutional structures and the relationship between stakeholders would have a direct impact on governance, management and development of local tourism".

This implies how tourism management is affected directly by the relationships between actors that are present in Egypt.

The analysis of these two hypotheses allowed understanding governance's issues and evaluation of the tourism management that could be applied, but also provided an opportunity to identify key work to promote Egypt globally as a safe tourism destination through several processes including public, private and local community who have an influence on the industry.

Interviews were conducted for four groups; central government, local government and non governmental organizations (NGOs). These groups are also segregated within themselves. Central government was represented by Ministry of Tourism, Ministry of Aviation, Ministry of Interior Affairs and Ministry of Transportation. Local government was represented governorates of the main tourist destinations (Like Luxor, Aswan, Sharm ElSheikh, Cairo, Hurgada and Alexandria). The private sector was represented by the Egyptian Tourism Federation and its five institutions. The last group was the local communities represented by the Non Governmental Organizations (NGOs).

The research focuses on the analysis of the current tourism management process taking place in Egypt and how governance and the relationship between stakeholders influence the area. At the same time, the research provides recommendations and a proposal of indicators to monitor impacts of tourism governance. In this research, stakeholders' awareness of current tourism management techniques were tested, their opinion for tourism development and management in Egypt and their institutional potential to contribute to this process were investigated. Their participation level and participation were surveyed. Additionally, the types of investments that should be implemented, and the financial resources needed in destination were investigated.

\section{Research Findings \\ Interview Findings \\ After conducting interviews, several findings were explored:}

Tourism governance concept was relatively new to all stakeholders questioned. However, they all recognized it as stakeholder partnerships. They all agreed that governance is a challenge. They pointed governance issues that had been previously identified and potentially amplified following the January $25^{\text {th }}$ revolution such as poor accountability, weak political parties, low citizen participation in political life, marginal role for representative civil society participation in monitoring outcomes of development, low trust of citizens in government, especially in the security forces, weak citizen's voice in setting 
development priorities, weak women's position in public and political life, violation of human rights practices in some state institutions.

All stakeholders agreed that tourism is a vital economic activity bringing benefits to all stakeholders involved. Private sector and NGOs agree that the public sector should reduce its direct involvement in tourism. Additionally, they agreed that several stakeholders do not know their exact role in managing tourism. Therefore, they suggested awareness campaign to resolve the issue of role ambiguity.

Tourism in Egypt has different views and horizons. First, all stakeholders have made various efforts to promote tourism. Taking into account the present reality in every tourist destination (including internal and external factors) and the potential of each destination, it is possible to observe the great heterogeneity regarding the level of development. Second, Egypt as a whole undergoes influence of public and private sectors, with different visions and, that have worked poorly without unified planning efforts.

All public services and private sectors are now doing different things. This limits the capacity of the tourism industry to work in different areas in an orderly manner, and this is unproductive, creating a level of desperation among the population. They agree that conflicts between the different actors have become increasingly intense, which in turn has negatively affected the sustainability of tourism development.

All interviewees pointed out the lack of financial resources as a problem. Yet, none of the stakeholders proposed a solution. However, according to the views of stakeholders, financial resources for the tourism projects should be met by private sector, public sector and NGO funds. Public financing proposals mainly focus on the Ministry of Tourism and local government. Together with these limited funds, foreign funds and foreign direct investment (FDI) for tourism investments are suggested.

All stakeholders agreed that Egyptian government has taken steps to create a favorable legislative and regulatory environment and to encourage investment in the tourism sector. It has also modernized its supporting infrastructure. A set of objectives has been developed that seek to ensure an appropriate institutional framework, safety, security and easy access to tourism locations, expansion of the product base, provision of the necessary infrastructure and superstructure, improvements to the quality of services, and promotion of the tourism product.

- The government is taking short- and long-term action to enhance the country's competitiveness in tourism. For example, in response to an identified gap in tourism human resources development, the ministry has been working with the Egyptian Tourism Federation (ETF) and industry stakeholders to develop training programs to improve the skills of all workers in the tourism industry, including middle and upper management.

- They all confirmed that although the Egyptian tourism sector has seen positive progress in recent years, the full value of the tourism industry still remains to be exploited. The shortage of an adequately qualified workforce, an underdeveloped transport network and infrastructure, impediments in the structural and institutional framework, the breaching of environmental regulations, and the high cost of doing business for SMEs, are some of the current problems facing the development of a sustainable tourism industry in Egypt. These 
issues will require continuous effort on behalf of the government to remove obstacles to success, accommodate global challenges and improve competitiveness.

- They all agreed that collaborative marketing efforts should be done to promote Egyptian tourism in the global context. All parties should be involved to achieve mutual benefits from the tourism activity practiced.

- Another important issue is that local communities in all tourist destinations observed do not have a vision of empowerment; there is a lack of compromise in relation to its future destiny. This is due to absence of coordinated tourism planning. They should see the destination as a whole and using tourism as a tool for achieving sustainability and prosperity. This requires the participation and coordination of major stakeholders.

- The private sector representatives suggested the various governmental institutions should work together for a common goal to prevent conflict of work and the repetition this will improve the tourism management process

\section{Literature Review Findings}

An inductive approach was adapted to explore the impact of tourism governance as a managing technique for Egyptian tourism. This was done through analyzing 15 research paper in relevant fields. The findings was as follows

- Researchers agree that both public and private sectors in a destination should be effectively governed, with best practice being applied in the development of governance principles and collaborative theories. Coordination, collaboration, and cooperation among different actors along the tourism destination can facilitate consensus and learning during the destination planning and management process, which in turn could ensure the protection of the public interest.

- Some researchers have found that there are conflicts and challenges during collaborative tourism destination management, caused by conflict of power and conflict of interests as well as contextual factors such as history, markets, culture, legislation, and politics (Wesley and Pforr 2010; Okazaki 2008; Trousdale 1999). Others have explored the effectiveness of the various governance models in tourism destination planning and management (Beritelli 2011; Erkuş-Öztürk and Eraydın 2010; Lade 2010) and indicated that it is the best solution for managing tourism destination.

- Researchers agree that inter-organizational governance is essential for tourism policy making, destination planning and management, destination marketing, integration of distribution channels, and sustainability, attention should first be paid to the governance environment(Wesley and Pforr 2010; Okazaki 2008)

- Governance mechanisms refer to the safeguards that organizations put in place to regulate inter- organizational exchange, minimize exposure to opportunism, protect transaction specific investments, and promote a continued relationship (Burkert, Ivens, and Shan 2012; Jap and Ganesan 2000). The deployment of appropriate governance mechanisms is critical for effective inter- organizational governance in the tourism value chain, as it 
could decrease transaction and coordination costs while increasing organizations' willingness to create value during tourism governance process (Jap and Ganesan 2000)

- Effective inter- organizational governance in tourism could benefit the development of the industry and facilitate the achievement of more sustainable outcomes(Wesley and Pforr 2010). It has been argued that governance has the potential to foster partnerships, cooperation, and collaborative arrangements, which in turn could promote more equitable and efficient economic performance between different actors (Wesley and Pforr 2010).

After presenting research findings, research hypotheses are accepted. Coordination and collaboration between stakeholders is essential for tourism management. Every stakeholder should have a clear role and transparent information to manage tourism destinations effectively. Additionally, development of direct relationships between various government agencies, especially between local actors at the same level and communication between stakeholders should be initiated through construction of the basic terminology and standardization of basic applications.

\section{Conclusion}

Tourism governance refers to the rules and mechanism for developing policies and business strategies which could combine all stakeholders. Egypt include a large network of public, private and local community partners who have a diversity of interests and perspectives, but also include a variety of economic activities that, taken together, make the tourism management a challenge. Development of direct relationships between various government agencies, especially between local actors at the same level and communication between stakeholders should be implemented through construction of the common activities and standardization of applications. Additionally, alternative management techniques that allow for flexible applications should be used in cases of different problem types occurring in the area should be encouraged. Indeed, there is a certain level of governance but that is very complicated, with a lack of information and little parallel efforts among stakeholders. There is no hierarchical governance because despite the existence of a hierarchy from the government, it does not operate properly. Moreover, this hierarchy does not extend to the private or community level and there are no clear regulations governing the collaboration efforts. Finally, communities must change their vision and be active participants of tourism management process. To achieve this goal of empowerment there must be a compromise of locals, but also it is necessary that other public and private actors work closely to give security to community.

\section{References}

Beritelli, P (2011). Cooperation among prominent actors in a tourist destination. Annals of Tourism Research, 38(2): 607-629.

Burkert, M., B. S. Ivens, and J. Shan. (2012). "Governance Mechanisms in Domestic and International Buyer-Supplier Relationships: An Empirical Study.” Industrial Marketing Management, 41 (3): 544-56.

Calame, Pierre (2009), Haciaunarevolución de la gobernanza. Reinventar la democracia. Chile, LOM ediciones.

Connelly, Greg (2007), “Testing Governance- A Research Agenda for Exploring Urban Tourism Competitiveness Policy: The Case of Liverpool 1980 - 2000", en Tourism Geographies, Vol. 9, No. 1, pp. 84-114. 
Erkuş-Öztürk, H., and A. Eraydın. (2010). "Environmental Governance for Sustainable Tourism Development: CollaborativeNetworks and Organization Building in the Antalya Tourism Region.” Tourism Management, 31 (1): 113-24.

De Oliviera J. (2002) Implementing environmental policies in developing countries through decentralization: the case of protected areasin Bahia, Brazil, World Development, 30 (10)pp1713- 1739

Frechtling, D. (2013), The Economic Impact of Tourism: Overview and Examples of Macroeconomic Analysis, UNWTO Statistics and TSA Issue Paper Series

Gray, T. S (2005) Theorizing about participatory fisheries governance. In Gray, T.S (eds.) Participatory fisheries governance, Springer, Netherland, p.p 1- 366

Hall, C.M. (1998) 'The institutional setting - tourism and the state', in D. Ioannides and K.G. Debbage (eds) The Economic Geography of the Tourist Industry. A supply-side analysis, pp. 199-219. London: Routledge

HwanSuk, C, C, Sirakaya, E, (2006), 'Sustainability indicators for managing community tourism', Tourism Management, 27: 1274-1289

Jap, S. D., and S. Ganesan. (2000). "Control Mechanisms and the Relationship Life Cycle: Implications for Safeguarding Specific Investments and Developing Commitment." Journal of Marketing Research, 37 (2): 227-45.

Jeffries, D. (2001) Governments and tourism Oxford: Butterworth-Heinemann

Kjær, Anne Mette (2004), Governance. Great Britain: Key Concepts.

Kooiman, J. (2000) 'Societal Governance: Levels, modes and orders of social political interaction', in J. Pierre (ed.) Debating Governance. Authority, Steering and Democracy, pp. 138-164. Oxford: Oxford University Press.

Kooiman, J., et al. (2008) 'Interactive Governance and Governability: An Introduction', The Journal of Transdisciplinary Environmental Studies 7(1): 1 - 11.

Lade, C. (2010). "Developing Tourism Clusters and Networks: Attitudes to Competition along Australia's Murray River.’Tourism Analysis, 15 (6): 649-61.

Noferini, Andrea (2011), Desarrollo, cooperacióndescentralizada y gobernanzamultinivel: consideracionespara la actualidad (Online), available: http://www.observ-ocd.org/

Nordin, Sand Svensson, B (2007) "Innovative destination governance: The Swedish ski resort of Åre", TheInternational Journal of Entrepreneurship and Innovation, Volume 8, Number 1, pp. 53-66(14)

OECD (2014) Country Profile. Tourism trends and Policies - Egypt , OECD

Okazaki, E. (2008). "A Community-Based Tourism Model: Its Conception and Use." Journal of Sustainable Tourism, 16 (5):

511-29.

Trousdale, W. J. (1999). "Governance in Context: Boracay Island, Philippines." Annals of Tourism Research, 26 (4): 840-67.

World Tourism Organization (2013), Governance for the tourism sector and its measurement, UNWTO Issues paper Series, UNWTO, Madrid.

World Travel and Tourism Council (2015) the Travel and Tourism Economic Impact: Egypt 2015, WTTC

Wesley, A., and C. Pforr. (2010). "The Governance of Coastal Tourism: Unraveling the Layers of Complexity at Smiths Beach,Western Australia." Journal of Sustainable Tourism, 18 (6): 773-92.

World Bank (2009), World Development Report: The State in a Changing World, Oxford University, Press New York. 


\section{Biography}

Dr Yasmine Hussein Ramzy, Associate Professor of Tourism Economics. I work in College of Management and Technology at Arab Academy for Science, Technology and Maritime Transport (Egypt) since 1999. I obtained my PhD degree from Faculty of Tourism and Hotels from Faculty of Tourism and Hotels at Alexandria University in 2009. My Major is Tourism. 